\title{
Abnormal Rhythms Associated with Persistent Left Superior Vena Cava
}

\author{
Kazuo Momma $^{[47]}$ and Leonard M. Linde \\ Division of Cardiology, Department of Pediatrics, University of California School of Medicine, \\ Los Angeles, California, USA
}

\begin{abstract}
Extract
The electrocardiograms of 26 patients with persistent left superior vena cava (SVC) draining into the coronary sinus were reviewed. Left axis of $\mathrm{P}$ waves between +15 and -29 degrees was observed in nine cases, including two of three cases of persistent left SVG with absent right SVC. Isorhythmic A-V dissociation with interference was observed in one subject.

The study of the $\mathrm{P}$ wave in five groups of patients with presumably normal caval drainage revealed that frontal $\mathrm{P}$ wave axis fell usually between +20 and +70 degrees.
\end{abstract}

\section{Speculation}

Left axis of the $\mathrm{P}$ waves, if present in patients with congenital heart defects, may suggest persistent left superior vena cava draining to the coronary sinus. Further pathologic and histologic study is needed to clarify the pathogenesis of these abnormal cardiac rhythms and the possible embryologic relation between persistent left superior vena cava and an ectopic pacemaker.

\section{Introduction}

Abnormal rhythms occur in some patients with congenital heart disease. Coronary sinus rhythm, nodal rhythm, wandering pacemaker, atrioventricular dissociation and left atrial rhythm have been reported $[6,7,19,21,22,25,27,28]$. These abnormal rhythms have been observed mainly in patients with complex cardiac anomalies accompanied by dextrocardia [17, $23,27]$, levocardia with abdominal situs inversus $[6,7$, $25,26]$ or anomalies of the venae cavae [11]. Since pacemaker tissue develops next to the junction of the superior vena cava (SVC) and the right atrium [29], abnormal rhythms associated with congenital heart disease may be related to embryologic abnormalities in development and location of the superior vena cava.
This report describes the frequency and types of abnormal rhythms found in patients with persistent left SVC draining to the coronary sinus and the electrocardiographic features that may be helpful in diagnosis of anomalies of superior vena caval drainage.

\section{Material and Methods}

Twenty-six patients with persistent left SVC draining into the coronary sinus were studied at the University of California Medical Center at Los Angeles from 1960 to 1967 . Of the 26, 12 were males and 14 were females. Ages ranged from five days to 15 years; all had normally placed hearts. The major cardiovascular malformations present in these patients and clinical and 
electrocardiographic data are tabulated in table I. All patients had congenital heart disease in addition to persistent left SVG. Anomalies were confirmed by postmortem examination of 5 patients and by operation or cardiac catheterization of 21 patients. The criteria of KeITH [17] were used to determine the atrial position; the right atrium is the chamber that receives the venae cavae and the coronary sinus, or a majority of these. All patients had normally situated atria. Cardiac malformations included 10 patients with ASD, eight with tetralogy of Fallot and five with VSD.

Thirteen lead (including $V_{3 R}$ ) electrocardiograms on all patients were studied. Tracings were obtained before operation and before administration of digitalis with the exception of patient No. 8. Electrocardiograms of this patient were available only during administration of digitalis (table I). All ECG records were examined for transient abnormal rhythms. The $\mathrm{P}$ waves were examined for height, duration, frontal plane axis, transverse plane axis, and configuration, particularly in leads $V_{1}, V_{2}, V_{5}$, and $V_{6}$. The $P-R$ interval was noted with regard to age and heart rate.

The established electrocardiographic criteria $[3,16]$ for nodal rhythm, $\mathrm{A}-\mathrm{V}$ block and $\mathrm{A}-\mathrm{V}$ dissociation were followed in this study. Frontal plane $\mathrm{P}$ wave axis was determined by use of the triaxial reference frame [20]. Transverse plane $P$ wave axis was determined using reference frames suggested by Mirowski [21]. Those regular $P$ waves with normal $P-R$ interval and normal rate were grouped according to the frontal plane axis as follows:
A. Extreme left axis (or coronary
sinus rhythm [33])
B. Left axis
C. Intermediate axis
D. Vertical axis
E. Right axis (or left atrial

$$
\begin{aligned}
& -89 \text { to }-30^{\circ} \\
& -29 \text { to }+15^{\circ} \\
& +16 \text { to }+75^{\circ} \\
& +76 \text { to }+105^{\circ}
\end{aligned}
$$$$
+106 \text { to }+270^{\circ}
$$

rhythm [36])

As a control, the $\mathrm{P}$ wave was studied in five groups of patients with presumably normal caval drainage that had been studied by cardiac catheterization and angiocardiography. These groups, selected because they exhibited the most common lesions associated with abnormalities of venae cavae, included 13 patients with ostium secundum atrial septal defect (ASD), 10 with ventricular septal defect (VSD), 10 with complete A-V canal, 11 with tetralogy of Fallot and 11 normal children without heart disease.

\section{Results}

The frontal plane $\mathrm{P}$ wave axes of the control groups were between +20 and +70 degrees, except in the two patients with ASD (fig.2). All frontal plane P wave axes of normal children were between +40 and $+60^{\circ}$. The mean frontal plane $\mathrm{P}$ wave axis of these groups was $38^{\circ}$.

The transverse plane $\mathbf{P}$ wave axes of the electrocardiograms of these groups showed rather wide variation and were between -10 and $+90^{\circ}$ (fig. 4).

Electrocardiographic data: The mean frontal plane $\mathrm{P}$ wave axis was $22^{\circ}$. Nine patients showed $P$ waves of left axis (table I, figs. 1 and 2). Frontal plane $P$ wave axes in these nine patients were between +15 and $-20^{\circ}$, and transverse plane $\mathrm{P}$ wave axes ranged from +80 to $0^{\circ}$. Signs of left atrial hypertrophy (deep ter-

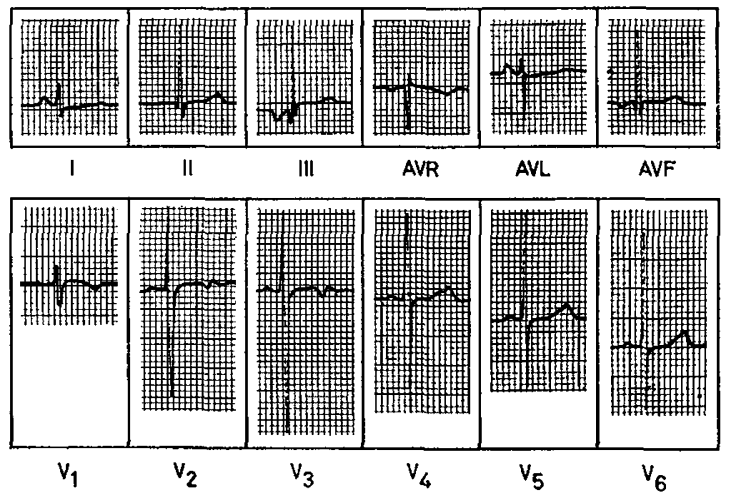

Fig. 1. Electrocardiogram of a 2-year-old boy with ASD (ostium secundum type), persistent left SVC draining into the coronary sinus and absent right SVC. The frontal plane $\mathrm{P}$ wave axis is approximately $-20^{\circ}$ (case 2).

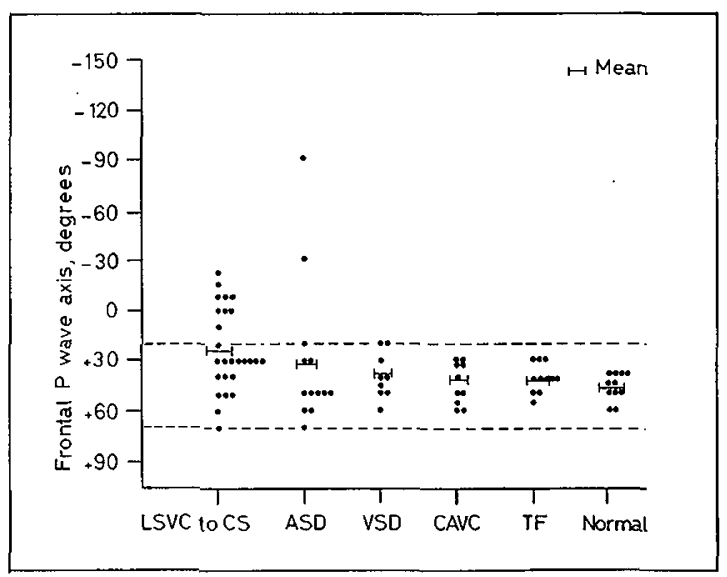

Fig.2. The frontal plane $\mathrm{P}$ wave axis of the electrocardiogram in six groups of patients showing a high incidence of left axis of $\mathrm{P}$ waves (less than $15^{\circ}$ or inverted in lead III) in patients with persistent left SVG draining into the coronary sinus. Two broken lines show normal upper and lower limits. 


\begin{tabular}{|c|c|c|c|c|c|c|c|c|c|}
\hline \multirow{2}{*}{$\begin{array}{l}\text { Patient } \\
\text { No. }\end{array}$} & \multirow{2}{*}{$\begin{array}{c}\text { Age } \\
\text { (years) }\end{array}$} & \multirow[t]{2}{*}{ Sex } & \multirow[t]{2}{*}{ Congenital anomalies } & \multirow[t]{2}{*}{ Rhythm } & \multirow[t]{2}{*}{ PR } & \multirow[t]{2}{*}{$\mathrm{HR}$} & \multicolumn{2}{|c|}{$\mathrm{P}$-axis } & \multirow{2}{*}{$\begin{array}{l}\text { Diagnosis } \\
\text { by }\end{array}$} \\
\hline & & & & & & & Front & Trans. & \\
\hline 1 & 2 & $\mathrm{~F}$ & $\begin{array}{l}\text { tetralogy of Fallot, absent right SVC, anomalous right } \\
\text { subclavian artery . . . . . . . . . . . . . . . . . . . . . . }\end{array}$ & $\mathrm{R}(\mathrm{B})$ & 0.15 & 120 & -10 & +80 & $\mathrm{CO}$ \\
\hline 2 & 2 & $\mathrm{M}$ & ASD, absent right SVC. . . . . . . . . . . . & $\mathrm{R}(\mathrm{B})$ & 0.12 & 120 & -10 & +30 & $\mathrm{CO}$ \\
\hline 3 & 5 & $\mathrm{M}$ & tetralogy of Fallot . . . . . . . . . . . . . . . . . & $\mathrm{R}(\mathrm{B})$ & 0.12 & 100 & -10 & +80 & $\mathrm{C}$ \\
\hline 4 & 4 & M & ASD, absent right SVG. . . . . . . . . . . . . . & $\mathrm{R}(\mathrm{G})$ & 0.12 & 110 & +30 & +55 & $\mathrm{C}$ \\
\hline 5 & 5 & $\mathrm{~F}$ & $\mathrm{ASD}, \mathrm{VSD} \ldots \ldots \ldots$ & $\mathrm{R}(\mathrm{B})$ & 0.16 & 85 & 0 & +10 & $\mathrm{CO}$ \\
\hline 6 & $1 / 12$ & M & VSD, ASD . . . . . . . . . . . . . . . . . . . . & $\mathrm{R}(\mathrm{B})$ & 0.10 & 140 & 0 & +50 & $\mathrm{C}$ \\
\hline 7 & 14 & $\mathrm{M}$ & ASD (sinus venosus defect type), partial anomalous & & & & & & \\
\hline & & & pulmonary venous drainage . . . . . . . . . . . . . . & $\mathrm{R}(\mathrm{B})$ & 0.16 & 70 & 0 & +70 & $\mathrm{CO}$ \\
\hline 81 & 1 & $\mathrm{~F}$ & $\mathrm{VSD} \ldots \ldots \ldots \ldots$ & $\mathrm{R}(\mathrm{B})$ & 0.14 & 140 & -15 & +20 & $\mathrm{CO}$ \\
\hline 9 & 2 & M & tetralogy of Fallot . . . . . . . . . . . . . . . . . & $\mathrm{R}(\mathrm{B})$ & 0.10 & 150 & +10 & +60 & OA \\
\hline 10 & 15 & $\mathrm{~F}$ & single ventricle, transposition of great vessels, PDA, ASD & $\mathrm{R}(\mathrm{B})$ & 0.22 & 70 & -20 & 0 & $\mathrm{G}$ \\
\hline 11 & 10 & $\mathrm{~F}$ & 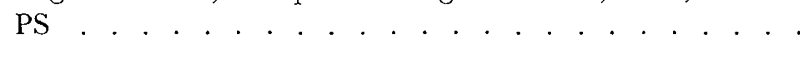 & $\begin{array}{l}\text { AVD and } \\
\text { R(C) }\end{array}$ & 0.16 & 100 & +40 & +10 & $\mathrm{CO}$ \\
\hline 12 & 4 & $\mathrm{~F}$ & $\mathrm{ASD} . . . . . . . . . . . . . .$. & $\mathrm{R}(\mathrm{G})$ & 0.12 & 85 & +30 & +30 & $\mathrm{CO}$ \\
\hline 13 & $4 / 12$ & $\mathrm{M}$ & tetralogy of Fallot, vascular ring, aberrant azygos vein. & $\mathrm{R}(\mathrm{C})$ & 0.12 & 130 & +40 & -10 & COA \\
\hline 14 & 4 & $\mathrm{M}$ & PDA, anomalous right subclavian artery . . . . . . & $\mathrm{R}(\mathrm{G})$ & 0.14 & 110 & +20 & +70 & CA \\
\hline 15 & 14 & $\mathrm{~F}$ & $\begin{array}{l}\text { tetralogy of Fallot, ASD, anomaly of lumbar vertebrae, } \\
\text { cleft palate, imperforate anus . . . . . . . . . . }\end{array}$ & $\mathrm{R}(\mathrm{C})$ & 0.16 & 85 & +30 & +50 & $\mathrm{CO}$ \\
\hline 16 & $4 / 12$ & $\mathrm{M}$ & total anomalous pulmonary venous drainage, ASD . . . & $\mathrm{R}(\mathrm{C})$ & 0.20 & 120 & +70 & 0 & $\mathrm{OA}$ \\
\hline 17 & $5 \mathrm{~d}$ & $\mathrm{~F}$ & truncus arteriosus . . . . . . . . . . . . . . . . . & $\mathrm{R}(\mathrm{C})$ & 0.12 & 150 & +50 & -10 & $\mathrm{G}$ \\
\hline 18 & 7 & $\mathrm{~F}$ & PS, aberrant renal vessels . . . . . . . . . . . . & $\mathrm{R}(\mathrm{G})$ & 0.12 & 95 & +30 & +10 & G \\
\hline 19 & 6 & $\mathrm{~F}$ & tetralogy of Fallot . . . . . . . . . . . . . . . & $\mathrm{R}(\mathrm{C})$ & 0.14 & 60 & +30 & +70 & OA \\
\hline 20 & 4 & M & ASD, PDA, partial anomalous pulmonary venous drainage & $\mathrm{R}(\mathrm{C})$ & 0.16 & 120 & +60 & +50 & $\mathrm{CO}$ \\
\hline 21 & $21 \mathrm{~d}$ & $\mathrm{~F}$ & single atrium, VSD, PS . . . . . . . . . . . & $\mathrm{R}(\mathrm{C})$ & 0.12 & 150 & +30 & +30 & $\mathrm{G}$ \\
\hline 22 & $\pi / 12$ & $\mathrm{~F}$ & tricuspid atresia, transposition of great vessels, PS & $\mathrm{R}(\mathrm{C})$ & 0.12 & 140 & +30 & 0 & $\mathrm{C}$ \\
\hline 23 & 2 & $\mathrm{~F}$ & tetralogy of Fallot . . . . . . . . . . . . . . . & $\mathrm{R}(\mathrm{C})$ & 0.12 & 140 & +30 & 0 & $\mathrm{G}$ \\
\hline 24 & 2 & M & ASD (endocardial cushion defect type) . . . . & $\mathrm{R}(\mathrm{C})$ & 0.16 & 130 & +40 & +80 & $\mathrm{C}$ \\
\hline 25 & 3 & $\mathrm{~F}$ & VSD . . . . . . . . . . . . . . & $\mathrm{R}(\mathrm{C})$ & 0.12 & 100 & +50 & +75 & $\mathrm{G}$ \\
\hline 26 & 1 & M & tetralogy of Fallot . . . . . . . . . . . . & $\mathrm{R}(\mathrm{C})$ & 0.12 & 120 & +50 & +60 & $\mathrm{C}$ \\
\hline
\end{tabular}

${ }^{1}$ ECG was taken during digitalis therapy. 


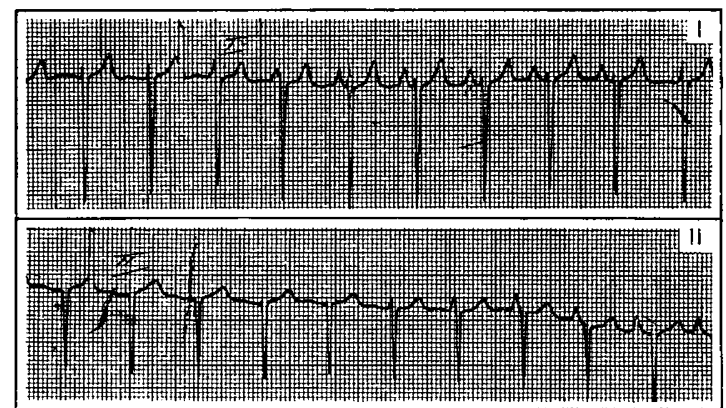

Fig.3. Electrocardiogram of a 10-year-old girl with severe pulmonic valvular stenosis and persistent left SVG draining into the coronary sinus. Note isorhythmic dissociation with interference (case 11).

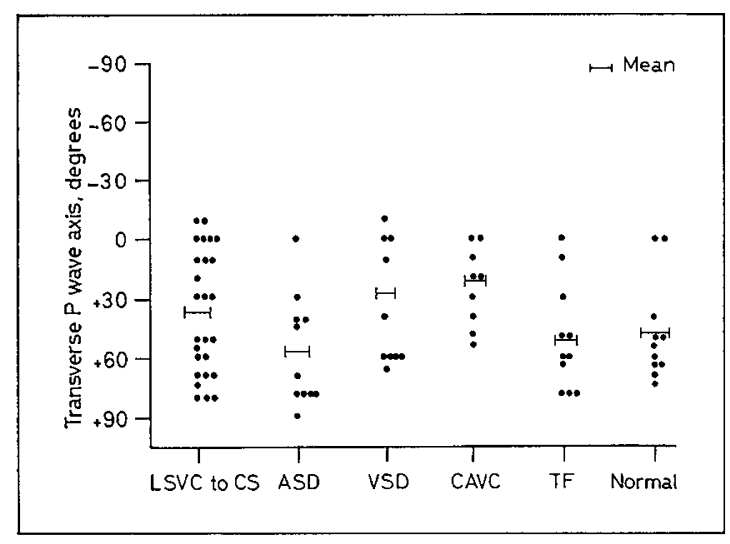

Fig.4. The transverse plane $\mathrm{P}$ wave axis of the electrocardiogram in six groups of patients.

\begin{tabular}{ll}
\hline Word Keys for Table I: \\
A & autopsy \\
ASD & atrial septal defect \\
G & heart catheterization and angiocardiography \\
d & day-old \\
F & female \\
HR & heart rate \\
IVC & inferior vena cava \\
M & male \\
O & operation \\
PDA & patent ductus arteriosus \\
PS & pulmonic stenosis \\
R(A) & \\
R(B) & classification of P-waves and rhythms; \\
R(C) & see text \\
R(D) & \\
R(E) & \\
SVC & superior vena cava \\
VSD & ventricular septal defect \\
\hline
\end{tabular}

minal negative deflection in $\mathrm{PV}_{1}$ and separation of two peaks in $\mathrm{PV}_{6}$ ) were observed in only one of these nine, patient No.10. Left axis of the $\mathrm{P}$ wave was present in two of three patients (Nos. 1, 2, and 4), in whom persistent left SVC draining into the coronary sinuses was associated with absent right SVC. One patient, No. 11, showed $\mathrm{A}-\mathrm{V}$ dissociation that was transient, isorhythmic, and incomplete. The $\mathrm{P}$ wave showed intermediate axis (fig. 3). The remaining 16 patients showed intermediate axis (table I, fig. 2).

The transverse plane $P$ wave axes are shown in table $\mathrm{I}$ and are compared with the $\mathbf{P}$ wave axes of the other groups in figure 4 . No significant differences in transverse plane $P$ wave axes were noted between the group with persistent left SVG and the control group. P-R intervals were within normal limits $(0.22$ and 0.20 seconds), except in patients Nos. 10 and 16 (table I). There was no significant difference in average P-R intervals in patients with intermediate $\mathrm{P}$ wave axis, compared with those with left $P$ wave axis. Heart rates were between 60 and 170). With the exception of patient No. 9, all patients with tachycardia of 150 or more were less than two months of age.

Hemodynamic data: Mean left atrial pressures, obtained by catheterization in seven patients, ranged between +5 and $+11 \mathrm{~mm} \mathrm{Hg}$. The average pressure of four patients with left frontal $P$ wave axis was $7 \mathrm{~mm}$ $\mathrm{Hg}$ and that of three patients with normal frontal $\mathrm{P}$ wave axis was $8 \mathrm{~mm} \mathrm{Hg}$. The averages of the mean right atrial pressure in six patients with left frontal plane $P$ wave axis and that in nine with normal axis were $6 \mathrm{~mm} \mathrm{Hg}$ and $5 \mathrm{~mm} \mathrm{Hg}$, respectively.

\section{Discussion}

Congenital structural defects of the heart and great vessels have been related to specific alteration of embryogenesis $[9,40]$. The possible embryonic origin of abnormal rhythms associated with congenital heart disease has not been considered. PAtTen [29] reported that the early embryonic heart appears to have two symmetrically placed pacemaking areas at the junction of the common cardinal veins with the horns of the sinus venosus. The right horn is incorporated into the dorsal wall of the right atrium during its formation, so that the sinoatrial node represents myocardium, originally a part of this sinus horn. The left pacemaking area, originally at the junction of the left common cardinal vein with the left sinus horn, may be carried down into its final location at or near the orifice of the coronary sinus [29]. Histologically, nodal tissue has been discovered repeatedly at the orifice of the coronary sinus $[33,37]$. This area is sometimes called the coronary sinus node [33]. Cells possessing electrochem- 
ical automaticity have been found in this location using microelectrodes [41]. Some investigators consider this area a part of the $\mathrm{A}-\mathrm{V}$ node [33].

The frontal plane $P$ wave axis in normal population has been studied by many authors $[4,10,19,32,36$, 43]. These studies and ours show that in the majority, the $P$ wave axes fall between +30 and +75 degrees, but a left axis as great as -30 degrees has been reported $[4,36,43]$. About 10 percent of the normal population shows $P$ wave axis between +30 and -30 degrees $[4$, $11,17,19,36]$. In the absence of intracardiac defects or abnormal caval drainage, these subjects usually exhibit a normal sinus rhythm [19].

An extensive survey of the literature $[3,4,16,17$, $19,33,36,43]$ revealed no satisfactory scheme for classification of regular cardiac rhythm according to frontal plane $P$ wave axis other than the descriptive terms 'normal' or 'coronary sinus rhythm' [34]. It appears that a more detailed classification of frontal $\mathrm{P}$ wave axis is possible and such a scheme has been used in this study.

Of the 26 patients in the present study, nine showed a $\mathrm{P}$ wave with left axis. A recent report by $\mathrm{HANCOCK}_{\mathrm{A}}$ [11] stated that a $P$ wave with left or extreme left axis was observed in 80 percent of patients with ASD of the sinus venosus type and in 70 percent of patients with persistent left SVC associated with various congenital heart defects other that ASD. Only one of 11 patients with atrial septal defect in this series was of the sinus venosus type. Left or extreme left axis of the $P$ waves has been observed also in patients with complex congenital cardiac anomalies such as polysplenia syndrome without persistent left SVG [28], but rarely in presumably normal individuals $[5,35,43]$.

The left axis deviation $\left(-29\right.$ to $\left.+15^{\circ}\right)$ of $\mathrm{P}$ waves in this series cannot be explained by left atrial hypertrophy, since most of the patients had no hemodynamic basis for left atrial overloading. Left axis deviation of the $P$ wave suggests, therefore, that the impulse originates at the middle or lower part of the right atrium and spreads mainly leftward rather than downward [1], or that the impulse originates at the S-A node, but is propagated along abnormal atrial conducting pathways.

The coronary sinus node is a possible site of impulse formation $[6,42]$. In hearts with persistent left SVC draining into the coronary sinus, an enlarged coronary sinus might be accompanied by functionally welldeveloped pacemaker tissue derived originally from the left sinus horn. If the impulse formation of this pacemaker is more rapid than that of the S-A node, wandering or shifting of the pacemaker and $\mathrm{P}$ waves, with left or extreme left axis, could result. Two of the three patients with persistent left SVG and absent right SVC showed left $\mathrm{P}$ wave axis. Possibly, embryo- logic failure in development of a right SVC and S-A node leads to a persistent left SVC and a functioning node at the coronary sinus [6].

It has been assumed that abnormal $\mathrm{P}$ waves result solely from abnormal sites of origin of atrial depolarization. Specific atrial pathways may exist $[2,15,31$, $38,41]$ and may provide linear and accelerated impulse spread $[13,41]$. The abnormal $P$ waves found in patients in this study may have resulted from abnormal atrial pathways of conduction rather than abnormal origins of activation. HolzmanN [13] reported that a conduction block between the sinus node and the upper part of the right atrium may cause theoretically inverted $P$ waves in leads II and III with a short $P-R$ interval, a configuration indistinguishable from the so-called upper nodal rhythm. Histologic study is necessary to determine whether an ectopic pacemaker or abnormal atrial conduction is responsible for the abnormal $\mathrm{P}$ waves with left axis reported in this paper.

Geometric change of the left atrium is a possible mechanism of left axis deviation of the frontal $P$ wave axis in persistent left SVC drainage into the coronary sinus. In some instances, the coronary sinus is so dilated that the left atrium may be displaced upwards [8]. Such displacement of the left atrium may explain some of the left axis deviation of the frontal $\mathrm{P}$ wave axis observed in this series.

Isorhythmic A-V dissociation with interference, seen in one patient, is a relatively rare arrhythmia in patients with congenital heart disease. Abnormally increased rhythmicity of the nodal area $[3,14,16]$ or bundle of His [12] has been assumed to cause this arrhythmia.

A persistent left superior vena cava may drain to the left atrium or to the left side of a single atrium, particularly with asplenia or the polysplenia syndrome $[9,24,39]$. In patients with bilateral right-sidedness or left-sidedness, associated cardiac anomalies are more complex [24, 39], and abnormal cardiac rhythms such as coronary sinus rhythm, left atrial rhy thm or wandering pacemaker are very common $[28,30]$. No coronary sinus or left atrial rhythms were observed in any of the 26 patients in the present study. Therefore, these patients are different from those with asplenia or polysplenia syndrome with regard to cardiac rhythms, clinico-pathologic picture and embryology.

\section{Summary}

Abnormal rhythms may occur in patients with congenital heart disease, particularly in association with complex lesions. Electrocardiographic tracings of 26 patients with persistent left superior vena cava draining into the coronary sinuses were examined. Left axis of 
the $\mathrm{P}$ waves between +15 and $-20^{\circ}$ was observed in nine of these patients, and isorhythmic A-V dissociation with interference was seen in one patient.

In a control group, frontal $\mathrm{P}$ axis was usually between +20 and $+70^{\circ}$. Left axis of the $P$ waves in patients with congenital heart defects may suggest the presence of persistent left superior vena cava draining into the coronary sinus.

A more detailed classification of the $P$ wave axis is suggested.

\section{References and Notes}

1. Abildskov, J.A.; Barnes, T. G. and H'sey, B.L. : Studies of normal and ectopic atrial excitation. Amer. Heart J. 52: 496 (1956).

2. Bachmann, G.: The inter-auricular time interval. Amer.J.Physiol. 41: 309 (1916).

3. Bexlet, S.: Clinical disorders of the heart beat (Lea and Febiger, Philadelphia 1963).

4. Burch, G.E. and DePasquale, N.P.: Electrocardiography in the diagnosis of congenital heart disease (Lea and Febiger, Philadelphia 1967).

5. Burnett, C.T. and TAylor, E.L.: Electrocardiograms of 167 average healthy infants and children. Amer. Heart J. 11: 185 (1936).

6. Campbell, M. and Reynolds, G.: The significance of the direction of P-wave in dextrocardia and isolated levocardia. Brit. Heart J. 14: 481 (1952).

7. Campbell, M. and Forgacs, P.: Levocardia with transposition of the abdominal viscera. Brit. Heart J. 15: 401 (1953).

8. Campbell, M. and Deuchar, D.C.: The leftsided superior vena cava. Brit. Heart J. 16: 423 (1954).

9. DE LA CRUz, M.V. and DA Rocha, J.P. : An ontogenetic theory for the explanation of congenital malformations involving the truncus and conus. Amer. Heart J. 51: 782 (1956).

10. Green, E.W.: Electrocardiographic pattern of atrial enlargement and abnormal impulse formation and conduction; in Electrocardiography in infants and children (ed. Cassers, D. E. and ZreGLER, R.E.) (Grune and Stratton, New York 1966).

11. HANCock, E.W.: Coronary sinus rhythm in sinus venosus defect and persistent left superior vena cava. Amer.J. Cardiol. 14: 608 (1964).

12. Hoffman, B.F. and CRanefield, P.F.: The physiological basis of cardiac arrhythmias. Amer.J. Med. 37: 670 (1964).

13. Holzmann, M.: Klinische Elcktrokardiographie, p. 196 (Thieme, Stuttgart 1965).

14. Jacob, D.R.; Donoso, E. and FriedberG, C. K.:
A-V dissociation. A relatively frequent arrhythmia. Analysis of thirty cases with detailed discussion of the etiologic significance of digitalis, physiologic mechanisms and differential diagnosis. Medicine, Balt. 40: 101 (1961).

15. James, T.N.: The connecting pathways between the sinus node and $\mathrm{A}-\mathrm{V}$ node and between the right and left atrium in the human heart. Amer. Heart J. 66: 498 (1963).

16. KAtz, L. N. and Prck, A.: Clinical electrocardiography. I. The arrhythmias (Lea and Febiger, Philadelphia 1956).

17. Keith, J.D.; Rowe, R.D. and VLAD, P.: Heart disease in infancy and childhood, 2nd ed. (Macmillan, New York 1967).

18. Laubry, C.; Soulié, P. et Vincent, P.: Troubles du rythme sinusal et de la conductibilité auriculoventriculaire dans deux cas de maladie congénital de cœur. Arch. Mal. Cœur 31: 1 (1938).

19. Lepschkin, E. : Modern electrocardiography, vol. I (Williams and Wilkins, Baltimore 1951).

20. Lipman, B.S. and Massie, E.: Clinical scalar electrocardiography, 5th ed. (Year Book, Chicago 1965).

21. Mrrowski, M.; Neill, C.A. and Taussig, H.B.: Left atrial ectopic rhythm in mirror-image dextrocardia and in normally placed malformed hearts. Report of twelve cases with 'dome and dart' $\mathbf{P}$ waves. Circulation 27: 864 (1963).

22. Mirowski, M.: Left atrial rhythm. Diagnostic criteria and differentiation from nodal arrhythmia. Amer.J. Cardiol. 17: 203 (1966).

23. Mirowski, M.; Neill, C.A.; Bahnson, H.T. and TAussig, H.B.: Negative $P$ waves in lead $I$ in dextrocardia. Circulation 26: 413 (1962).

24. Moller, J.H.; Nakib, A.; Anderson, R. C. and Edwards, J.E.: Congenital cardiac disease associated with polysplenia: A developmental complex of bilateral 'left-sidedness'. Circulation 36: 789 (1967).

25. Momma, K.; Tanae, A.; Oshima, M. and OKuni, M.: Levocardia with abdominal situs inversus. Report of eight cases with special references to their electrocardiographic findings. Jap. Heart J. 5: 243 (1964).

26. Momma, K. and Linde, L. M.: Abnormal rhythms associated with absent inferior vena cava (in preparation).

27. NeIll, C.A. and Mirowski, M. : Dextrocardia; in electrocardiography in infants and children (ed. Cassels, D.E. and Ziegler, R.F.), p.324 (Grune and Stratton, New York 1966).

28. Ongley, P.A.; Titus, J.L.; Khoury, G.H.; Rahimtoola, S.H.; Marshall, H.J. and EdWARDS, J.E.: Anomalous connection of pulmonary 
veins to right atrium associated with anomalous inferior vena cava, situs inversus and multiple spleen: A developmental complex. Mayo Clin. Proc. 40: 609 (1965).

29. Patten, B.M.: The development of the sinoventricular conduction system. Univ. Michigan Med. Bull. 22: 1 (1956). (Cited from GouLD's Pathology of the heart.)

30. Puecr, P.: L'activité électrique auriculaire normale et pathologique (Masson, Paris 1956).

31. Roвb, J.S. and Petri, R.: Expansions of the atrioventricular system in the atria; in The specialized tissues of the heart (ed. Paes deCarvalho, A.; deMello, W.C. and Hoffman, B.F., p. 1 (Elsevier, Amsterdam 1961).

32. Sano, T.; Hellerstein, H.K. and Vayda, E.: $\mathrm{P}$ vector loop in health and disease as studied by the technique of electrical dissection of the vectorcardiogram (differential vectorcardiography). Amer. Heart J. 53: 854 (1957).

33. Scherf, D. and Coren, J.: The atrioventricular node and selected cardiac arrhythmias (Grune and Stratton, New York 1964).

34. Scherf, D. and HARRIs, R. : Coronary sinus rhythm. Amer. Heart J. 32: 443 (1946).

35. Shipley, R.A. and Hallaran, W.R.: The fourlead electrocardiogram in two hundred normal men and women. Amer. Heart J. 11: 325 (1913).

36. Sodi-Pallares, D. and Galder, R. M. : New basis of electrocardiography (Mosby, St. Louis 1956).

37. Tawara, S.: Die Topographie und Histologie der Brückenfasern. Ein Beitrag zur Lehre von der Bedeutung der purkinjeschen Fäden. Zbl. Physiol. 19: 70 (1905).
38. Thorel, C.: Vorläufige Mitteilung über eine besondere Muskelverbindung zwischen der Cava superior und dem Hisschen Bündel. Münch.med. Wschr. 56: 2159 (1909).

39. van Mierop, L.H.S.; Patterson, P.R. and ReyNoLDs, R.W.: Two cases of congenital asplenia with isomerism of the cardiac atria and the sinoatrial nodes. Amer. J. Cardiol. 13: 407 (1964).

40. Van Praagh, R.; Van Praagh, S.; Vlad, P. and KeITH, J.D.: Anatomic types of congenital dextrocardia. Diagnostic and embryologic implication. Amer.J. Cardiol. 13: 513 (1964).

41. Wagner, M.L.; Lazzara, R.; Weiss, R. M. and HofFman, B.F.: Specialized conducting fibers in the interatrial band. Circulat. Res. 18: 502 (1966).

42. Zarn, A.: Experimentelle Untersuchungen über Reizbildung und Reizleitung im Atrioventrikularknoten. Arch.ges. Physiol. 151: 247 (1913).

43. ZieGLER, R.F.: Electrocardiographic studies on normal infants and children (Thomas, Springfield, 1951).

44. Presented in part at the Thirty-eighth Annual Meeting of the Society for Pediatric Research, Atlantic City, N.J., May 4, 1968.

45. Supported by grants from the Los Angeles County Heart Association and the United States Public Health Service.

46. Dr. Momma is a recipient of a fellowship from the Los Angeles County Heart Association. He is a Trainee in Pediatric Cardiology under a program sponsored by the National Institutes of Health.

47. Requests for reprints should be addressed to: $\mathrm{KA}_{\mathrm{A}}$ zuo Mомма, M.D., Division of Cardiology, Dept. of Pediatrics, UCLA School of Medicine, Los Angeles, California 90024 (USA). 